\title{
長いき裂を有する窒化ケイ素の疲労き裂進展挙動
}

\author{
小笠原俊夫・安田榮—* \\ 日産自動車(株)総合研究所, 237 神奈川県横須賀市夏島町 1 \\ *東京工業大学工業材料研究所, 227 神奈川県横浜市緑区長津田町 4259
}

\section{Fatigue Crack Growth Behavior of Large Crack in Silicon Nitride}

Toshio OGASAWARA and Eiich YASUDA*

\author{
Nissan Research Center, Nissan Motor Co., Ltd., 1, Natsushima-cho, Yokosuka-shi 237 \\ *Research Laboratory of Engineering Materials, Tokyo Institute of Technology, 4259, Nagatsuta-cho, Midori-ku, Yokohama-shi
}

[Received May 25, 1993; Accepted August 18, 1993]

Fatigue crack propagation under cyclic loading was observed in CT specimens of silicon nitride by employing an electrical resistance technique with crack gage made of platinum film. The crack growth rate was not uniform even if the fatigue condition was constant. The crack growth behavior in maximum stress intensity factor $K_{\text {Imax }}$-increasing condition was different from that in $K_{\text {Imax }}$-decreasing condition. The effect of stress ratio $R\left(=\sigma_{\min } / \sigma_{\max }\right)$ was not significant when the minimum stress intensity factor $\left(K_{I \min }\right)$ was greater than crack opening stress intensity factor $\left(K_{\text {open }}\right)$. Fracture toughness measured by CT specimens after fatigue testing was smaller than that by SEPB method. The experimental results, indicated that the unloading may cause fretting and/or crashing of the asperities between the crack faces in silicon nitride, where toughening is achieved by grain bridging. Therefore, the cyclic loading may accelerate the static fatigue crack propagation caused by stress corrosion cracking.

Key-words : Silicon nitride, Fatigue, Crack growth, Fracture toughness, Crack bridging

\section{1. 緒言}

破壊力学試験片を用いた疲労き裂進展試験は，金属にお ける一般的な評価法の一つであり，寿命予測を行うために 必要なデータを取得することができる。また，材料の疲労 メカニズムを詳細に検討する目的でも, 疲労き裂進展試験 は有効である。セラミックスの疲労き裂進展が金属の場合 と最も異なる点は, き裂進展速度が Paris 則 $(\mathrm{d} a / \mathrm{d} N=$ $\left.A \Delta K_{\mathrm{I}}^{n}\right)$ では統一的に整理できず，

$$
\mathrm{d} a / \mathrm{d} t=A K_{\mathrm{I}}{ }^{n}
$$

で近似される点にある1),2)，ここで， $a, N, t$ はき裂長さ， 繰り返し数及び時間， $A, n$ はき裂進展パラメータ， $K_{\mathrm{I}}$ は 応力拡大係数である. (1) 式は一定の応力波形のもとで は，

$$
\mathrm{d} a / \mathrm{d} N=A K_{\max }^{p}
$$

で表される2)。ここで， $K_{\operatorname{Imax}}$ は繰り返し負荷における最 大応力拡大係数であり, $K_{\operatorname{Imax}}=Y \sigma_{\max } \sqrt{\pi a}$ ( $Y$ : き裂の形 状係数）で与えられる. 一般のセラミックス材料では破壊 勒性值（ $K_{\mathrm{IC}}$ ）の絶対值が小さいことに加えて，(1),(2)
式に㧍けるパラメータ $n$ は 20 以上という大きな值となる ため, 疲労き裂進展試験を, $K_{\mathrm{IC}}$ に近く, かつ狭い範囲 で，精度良く実施する必要がある。

このように，セラミックスの疲労き裂進展試験は金属の 場合と比較すると困難な要因も多いが，岸本ら ${ }^{3)}$ - 8),

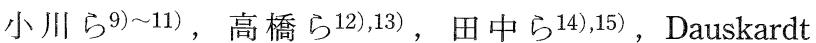
ら 16) 19) は破壊力学試験片を用いた疲労き裂進展試験を実 施し，き裂進展メカニズムに関する詳細な研究を行ってい る. 特に岸本と上野らによる研究によって, 高勒化機構と して粒子架橋が支配的な窒化ケイ素では, 繰り返し応力に よる粒子架橋領域の破壊が疲労き裂進展に大きな影響を及 ぼしていることが明らかになっている77,8)。また， Dauskardt らは PSZ や SiC-アルミナ複合材料のき裂進展 試験におけるき裂履歴の影響について詳細な研究を行い, 応力誘起変態や粒子架橋による Process zone及び Process zone wake の形成がき裂進展速度に大きな影響を 及ぼすことを報告している16) 19)。このことは，窒化ケイ 素の疲労き裂進展挙動も，き裂の履歷に大きく影響される ことを示唆している。

そこで本研究では，CT 試験片を用いた常圧焼結窒化ケ イ素の疲労き裂進展試験を実施し, 最大応力拡大係数 $\left(K_{\operatorname{Imax}}\right)$ を階段状に変化させる方法によって，窒化ケイ 素の疲労き裂進展挙動に及ぼす荷重履歴の影響に関する詳 細な実験を行った。また，窒化ケイ素の高勒化機構が主に 粒子架橋効果であるという前提のもとに，得られた実験結 果から繰り返し荷重下での疲労き裂進展挙動について考察 した。

\section{1 材料及び試験片形状}

\section{2. 実験方法}

実験に用いた材料は， $\mathrm{Al}_{2} \mathrm{O}_{3}(10 \mathrm{wt} \%)$ と $\mathrm{Y}_{2} \mathrm{O}_{3}(5 \mathrm{wt} \%)$ を焼結助剂とする常圧焼結窒化ケイ素であり，焼結温度 $1750^{\circ} \mathrm{C}$, 焼結時間 1 時間, 密度は $3.2 \mathrm{~g} / \mathrm{cm}^{3}$ である。機械 的特性は，4点曲げによる室温強度（JIS-R1601）は695 $\mathrm{MPa}$ ，共振法によるヤング率（JIS-R1602）は265 GPa， SEPB 法による破壞勒性（JIS-R1607）は，5.0 MPa $\sqrt{\mathrm{m}}$ となっている。

疲労試験片はASTM-E399で規定されたCT 試験片に 




(a)

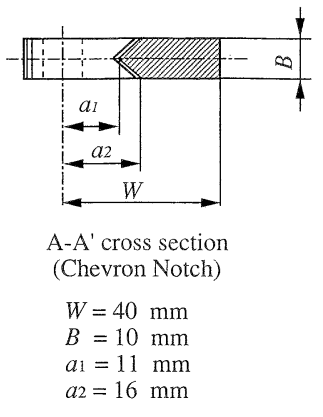

(b)
Fig. 1. Geometries and dimensions of CT specimen with a crack gage evaporated by platinum sputtering. Chevron notch was used to induce pre-cracking easily.

準じ，図1(a)に示す形状とした。このような試験片にス トレートノッチを導入しただけでは, 安定的に疲労予き裂 を導入することは困難であるため, 図 1 (b)に示す形状の シェブロンノッチを適用した4). 予き裂の導入条件は, 周 波数 $f=10 \mathrm{~Hz}$, 応力比 $R=\left(\sigma_{\min } / \sigma_{\max }\right)=0.1$, 最大応力拡 大係数 $K_{\operatorname{Imax}}=4.5 \mathrm{MPa} \sqrt{\mathrm{m}}$ である. シェブロンノッチ終 端から更に $2.5 \mathrm{~mm}$ の位置まで予き裂を進展させて, 疲労 き裂進展試験に使用した。

\section{2 き裂長さの測定法}

金属に打ける最も一般的なき裂計測法は，クリップゲー ジや歪ゲージを用いてき裂開口変位（COD） や背面歪 （BFS）を測定し，コンプライアンス法によってき裂長さ を計算する方法である，ところが，セラミックスは破壊勒 性が小さいことから，COD やBFS も著しく小さく，これ らの方法で精度良く疲労試験中のき裂長さを測定すること は困難である。そこで, 本研究では図 1 (a)に示すような 形状の厚さ約 $0.05 \mu \mathrm{m}$ の $\mathrm{Pt}$ 薄膜製クラックゲージを， ス パッタリング法によって試験片表面リガメント部に形成

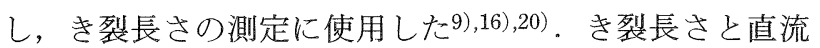
電位差の関係は, 沉用有限要素解析コードABAQUS (Hibbitt, Karlsson \& Sorensen, Inc.) によって計算し，校 正曲線を求めた. クラックゲージへは, 直流安定化電源 （アドバンテスト製， R6142）によって20 mA の定電流を 流し，図 1 (a)に示す V部の電位を測定した。このときの 初期電位は $1.5 \sim 2.5 \mathrm{~V}$ であった. クラックゲージ法によ るき裂読み取り精度は， $\pm 20 \mu \mathrm{m}$ 以下であった。

実験は油圧サーボ式疲労試験機（島津製作所製, EHFEA0.5）を使用した。荷重，COD，BFS，き裂長さを， $\mathrm{A} / \mathrm{D}$ 変換インターフェース（コンテック製, AD1216TA）を経由してパソコン（エプソン製，286VF）に取 り込み，これらをフィードバック信号として外部発振機 （NF 回路設計製，1920A）を介して疲労試験機を制御し, $K$ 值制御試験を実施した。この結果， $K_{\operatorname{Imax}}$ を \pm 0.05 $\mathrm{MPa} \sqrt{\mathrm{m}}$ 以内の精度で制御することが可能となった。 $\mathrm{COD}$ 及び BFS はクリップゲージ（インストロン製， 2670-004）及び背面歪ゲージ（共和電業製，KFG2-120）
によって測定し，負荷時のコンプライアンス変化点から， き裂開口の応力拡大係数も併せて測定した。

\section{3. 実験結果}

\section{$3.1 K_{\operatorname{lmax}}$ 漸減試験におけるき裂進展挙動}

周波数 $f=10 \mathrm{~Hz}$ ，応力比 $R=0.1$, サイン波の条件で, 2 本の試験片について $K_{\operatorname{Imax}}$ を段階状に減少させる $K_{\operatorname{Imax}}$ 漸減試験を実施した。図 $2(\mathrm{a}) \sim(\mathrm{d})$ は，それぞれ一定の $K_{\text {Imax }}$ に対応するき裂進展挙動を拡大表示した結果であ り，繰り返し数とクラックゲージ法で測定されたき裂長さ の関係を示したものである。微視的に見ると，き裂進展速 度は一様ではなく，停留や急激なき裂進展などを含む，不 均一な速度の進展挙動を示している。図 3 は, き裂進展速 度 $(\mathrm{d} a / \mathrm{d} N)$, 最大応力拡大係数 $\left(K_{\operatorname{Imax}}\right)$, き裂開口の応 力拡大係数 $\left(K_{\mathrm{open}}\right)$ と，き裂長さ $(a)$ との関係をプロッ トした結果である。裂進展速度は $K_{\operatorname{Imax}}$ 值を減少させる と同時に低下し，更に緩やかに速度が小さくなる傾向を示 している。この傾向は 2 本の試験片とも同じであった。

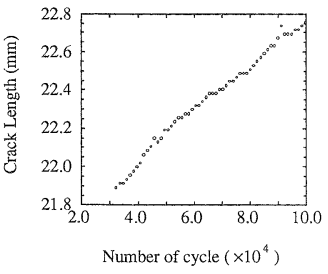

(a) $K_{\text {Imax }}=3.9 \mathrm{MPa} \vee \mathrm{m}, f=10 \mathrm{~Hz}, R=0.1$

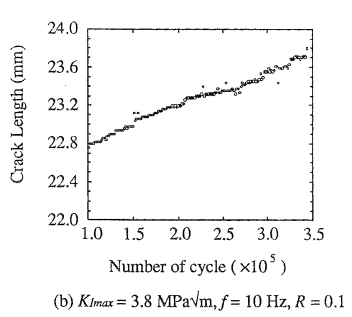

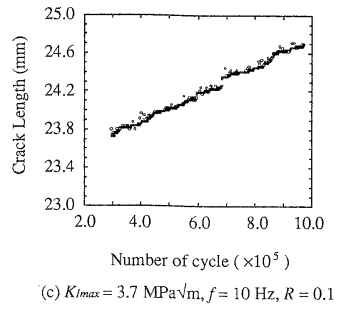



(d) $K I \max =3.6 \mathrm{MPa} \backslash \mathrm{m}, f=10 \mathrm{~Hz}, R=0.1$
Fig. 2. Detailed plotting of fatigue crack growth under $K_{\operatorname{Imax}}$ decreasing condition (Frequency $f=10 \mathrm{~Hz}$ and stress ratio $\sigma_{\min } /$ $\sigma_{\max }=R=0.1$ ). The maximum stress intensity factor $K_{\operatorname{Imax}}$ is (a) $3.9 \mathrm{MPa} \sqrt{\mathrm{m}}$, (b) $3.8 \mathrm{MPa} \sqrt{\mathrm{m}}$, (c) $3.7 \mathrm{MPa} \sqrt{\mathrm{m}}$, (d) 3.6 $\mathrm{MPa} \sqrt{\mathrm{m}}$, respectively. Even if the fatigue testing condition is constant, the crack growth rate is not uniform.

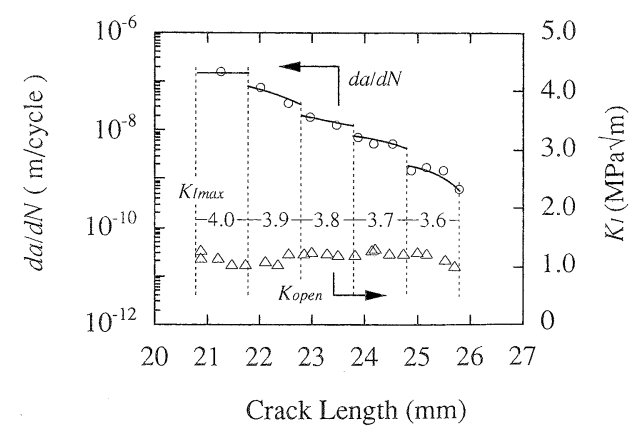

Fig. 3. Fatigue crack growth rate $(\mathrm{d} a / \mathrm{d} N)$ and maximum stress intensity factor $\left(K_{\operatorname{Imax}}\right)$ as a function of crack length $(a)$ under $K_{\text {Imax }}$ decreasing condition $(f=10 \mathrm{~Hz}, R=0.1)$. 
き裂開口の応力拡大係数は本実験の計測精度では差がみら れず，き裂開口の応力拡大係数 $K_{\text {open }}$ はき裂長さによらず 約1.2 $\mathrm{MPa} \sqrt{\mathrm{m}}$ と, 一定であった。

\section{$3.2 K_{\operatorname{Imax}}$ 漸増試験におけるき裂進展挙動}

図 4 は, 周波数 $f=10 \mathrm{~Hz}$, 応力比 $R=0.1$, サイン波の 条件で実施した $K_{\text {Imax }}$ 漸増試験における $K_{\text {Imax }}, K_{\text {open }}$ 及び $\mathrm{d} a / \mathrm{d} N$ と，き裂長さとの関係を示したものである。 $K_{\operatorname{Imax}}$ 漸減試験の場合とは異なって， $K_{\operatorname{Imax}}$ 值を増加するのと同 時に，き裂進展速度 $\mathrm{d} a / \mathrm{d} N$ も大きくなり，これはき裂進 展に依存せずほぼ一定となっている。 $K_{\text {open }}$ は $1.0 \sim 1.2$ $\mathrm{MPa} \sqrt{\mathrm{m}}$ 程度でほぼ一定である。き裂は $K_{\mathrm{Imax}}$ 漸減試験 と同様に，微視的には不均一な速度で進展していることが 認められた。

図 2 に示すようなき裂長さと繰り返し数の関係を直線 回帰することによっておの打のの最大応力拡大係数 $K_{\text {Imax }}$ に対するき裂進展速度を計算し，き裂進展線図上にプロッ トした結果を図 5 の四び○に示す。ここで，ははとは 異なる試験片を用いて $K_{\operatorname{Imax}}$ 漸減試験を実施した結果であ るが，データはほぼ一致している，疲労き裂進展パラメー 夕は, $K_{\operatorname{Imax}}$ 漸減試験の場合には $A=1.69 \times 10^{-34}, n=$ 43.7, 漸増試験の場合には $A=4.35 \times 10^{-22}, n=22.7$ であ り，大きく異なる值となった。

\section{3 繰り返し周波数及び応力比の影響}

応力比 $R=0.1$, サイン波, 最大応力拡大係数 $K_{\operatorname{Imax}}$ $=4.1$ 及び $3.9 \mathrm{MPa} \sqrt{\mathrm{m}}$ の一定の条件で, 周波数のみ $f=1,5,10(\mathrm{~Hz})$ と変化させた場合のき裂進展速度を図 6

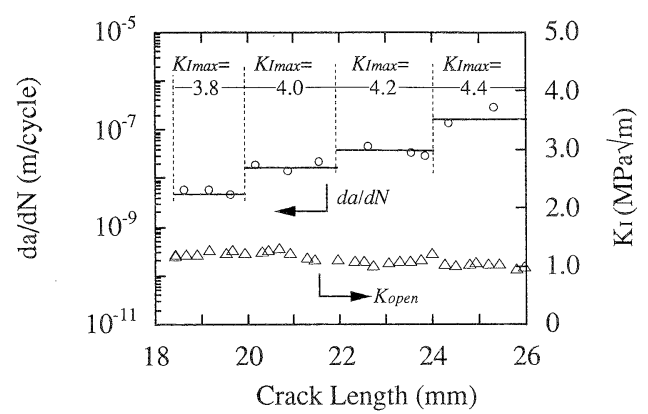

Fig. 4. Fatigue crack growth rate $(\mathrm{d} a / \mathrm{d} N)$ and maximum stress intensity factor $\left(K_{\text {Imax }}\right)$ as a function of crack length $(a)$ under $K_{\operatorname{Imax}}$ increasing condition $(f=10 \mathrm{~Hz}, R=0.1)$.

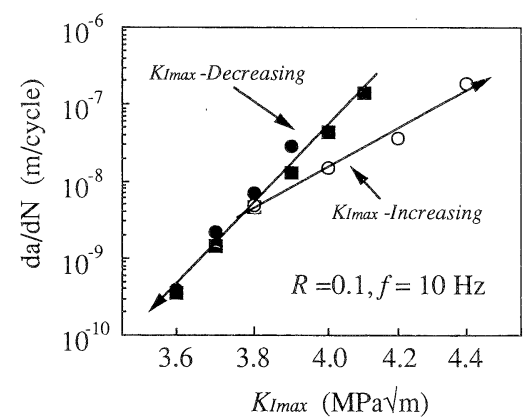

Fig. 5. Crack growth rate diagram $\left(K_{\operatorname{Imax}}-\mathrm{d} a / \mathrm{d} N\right.$ diagram $)$ under $K_{\text {Imax }}$ increasing and decreasing condition $(f=10 \mathrm{~Hz}, R=0.1)$.

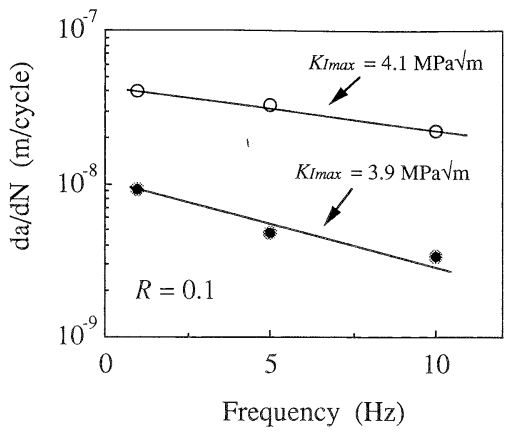

Fig. 6. Effect of frequency on fatigue crack growth rate under $R=0.1$.

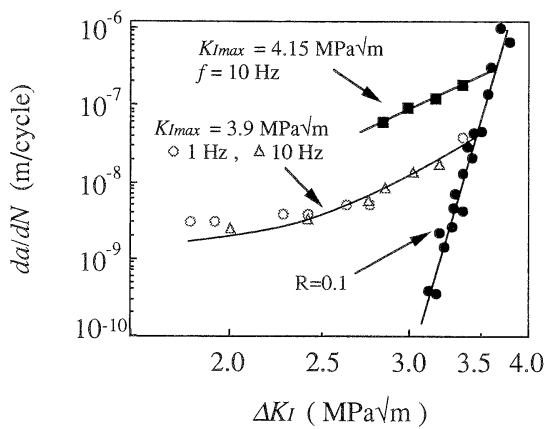

Fig. 7. Fatigue crack growth rate $(\mathrm{d} a / \mathrm{d} N)$ as a function of stress amplitude $\Delta K_{\mathrm{I}}$. The data were obtained by changing stress ratio under constant $K_{\operatorname{Imax}}(4.15$ or $3.9 \mathrm{MPa} \sqrt{\mathrm{m}})$.

に示す。き裂進展速度は，周波数の増加とともに遅くなる 傾向が認められる．同様の実験結果は岸本らによる詳細な 報告がなされており ${ }^{3)}$ ，繰り返し数ばかりでなく，負荷時 間も痩労き裂進展速度に大きく影響していることが分か る。

周波数 $f=10 \mathrm{~Hz}, K_{\operatorname{Imax}}=4.15$ 及び $3.9 \mathrm{MPa} \sqrt{\mathrm{m}}$ の条件 で，応力比の影響を調べた結果を図 7 のき裂進展線図上に 示す。ここで横軸は応力振幅 $\Delta K_{\mathrm{I}}\left(=K_{\mathrm{Imax}}-K_{\mathrm{Imin}}\right)$ であ る. 図中には $R=0.1, f=10 \mathrm{~Hz}$ の条件で $K_{\operatorname{Imax}}$ 漸減試験 によって得られたデータも同時にプロットしてある。(1) 式に示した時間依存型の SCG (Subcritical Crack Growth) モデルに従えば，応力比が大きくなると， 1 周期当たりの き裂進展量（速度）は大きくなる2)。ところが，K $K_{\text {Imax }}$ が 一定の場合, 応力振幅が小さい（応力比が大きい）ほどき 裂進展速度は小さくなっており，これはSCG モデルでは 説明できない。 $K_{\operatorname{Imax}}$ が一定の場合について，便宜的に Paris 則（ $\mathrm{d} a / \mathrm{d} N=A \Delta K_{\mathrm{I}}{ }^{n} ）$ を仮定したときのき裂進展パ ラメータの值は, $A=1.44 \times 10^{-10}, n=5.8\left(K_{\operatorname{Imax}}=4.15\right.$ $\mathrm{MPa} \sqrt{\mathrm{m}})$ ，及び $A=8.30 \times 10^{-11}, n=4.3\left(K_{\operatorname{Imax}}=3.90\right.$ $\mathrm{MPa} \sqrt{\mathrm{m}})$ であった. $K_{\mathrm{Imax}}=3.90 \mathrm{MPa} \sqrt{\mathrm{m}}$ では, $f=1$ $\mathrm{Hz}$ の実験も行ったが，図 7 に示すように周波数の影響は 顕著には認められなかった。

図 8 は, $K_{\operatorname{Imax}}=3.90 \mathrm{MPa} \sqrt{\mathrm{m}}$ のときの応力比と $K_{\text {open }}$ の関係を示した結果であるが， $K_{\mathrm{open}}$ はほぼ一定であり， 応力比 $R$ には依存しなかった。な抒 $\Delta K_{\mathrm{I}}<2.7 \mathrm{MPa} \sqrt{\mathrm{m}}$ 


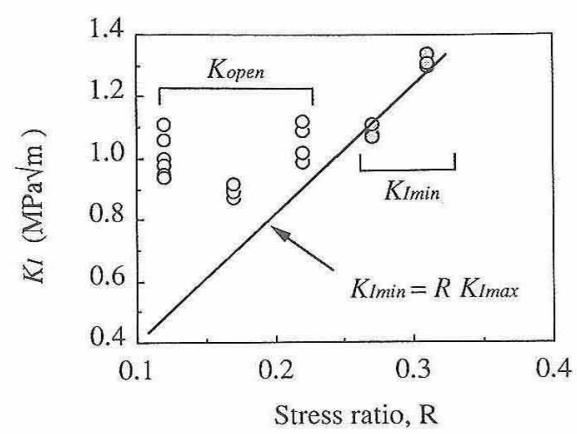

Fig. 8. Effect of stress ratio $(R)$ on crack opening stress intensity factor $K_{\text {open }}$ under $K_{\operatorname{Imax}}=3.9 \mathrm{MPa} \sqrt{\mathrm{m}}, f=10 \mathrm{~Hz}$. In $R>0.27$, crack closure was not observed.

$(R>0.30)$ の条件ではき裂の開口は観察されなかったた め, 図 8 では $K_{\operatorname{Imin}}$ をプロットしてある.

\section{4 き裂進展試験後の破壞勒性値}

き裂進展試験後の試験片は，材料試験機を用い, クロス ヘッド速度 $0.5 \mathrm{~mm} / \mathrm{min}$ の条件で引っ張り試験を行って, 破壞勒性值を測定した. 図 9 は, き裂進展後の破壊勒性值 を, 繰り返し疲労試験の最終 $K_{\operatorname{Imax}}$ の関数としてプロット したものである．ここで繰り返し疲労条件は，いずれも応 力比 $R=0.1$, 周波数は $f=10 \mathrm{~Hz}$ である. SEPB 法で測定 された破壊勒性值 $K_{\mathrm{IC}}=5.0 \mathrm{MPa} \sqrt{\mathrm{m}}$ に比較して全般に小



Max. Stress Intensity Factor, $K_{l \max }(\mathrm{MPa} \sqrt{\mathrm{m}})$

Fig. 9. Fracture toughness $\left(K_{\mathrm{IC}}\right)$ after cyclic fatigue testing under $f=10 \mathrm{~Hz}$ and $R=0.1$ as a function of $K_{\mathrm{Imax}} . K_{\mathrm{IC}}$ is small with $K_{\text {Imax }}$.
さな值となっており，特に疲労試験時の $K_{\operatorname{Imax}}$ が大きいほ ぞ $K_{\mathrm{IC}}$ は小さくなる傾向が認められる。データは若干ば らついているが，これは同じ $K_{\operatorname{Imax}}$ の場合でも応力の履歴 が扔の扔の異っていることが原因であると考えられる，

\section{4. 考 察}

岸本らは，窒化ケイ素の繰り返し疲労き裂進展に関する 一連の研究によって，(1)窒化ケイ素の繰り返し疲労は, 基本的に大気中水分の影響をうけた時間依存型の遅れ破壞 （応力腐食）であり，(2)繰り返し負荷による粒子架橋領 域の損傷によって応力遮蔽効果が低下し静荷重き裂進展を 加速することを明らかにしだ) ー8)．この結論は妥当なも のであって, 小川ら 10),11), 高橋ら ${ }^{13)}$, Dauskardt ら 16) 19), Guiu ら 21), Lathabai ら ${ }^{23)}$ によるマグネシア，アルミナ, ウイスカー強化アルミナ等の粒子架橋効果による高鞁化機 構が支配的なセラミックスに対する実験結果でも, 同様の 結論が得られている.そこで, 本研究でもこの立場からの 考察を試みる。

図10は，疲労き裂のSEM 観察結果である。図10(a)か らも明らかなように, き裂は屈曲しながら進展しており， 繰り返し負荷に怙けるき裂面の不整合や，フレッチング損 傷による摩耗片なども随所に観察された ${ }^{14)}$ ， 屯た図10(b) は，架橋した柱状粒子が，ディボンディング後に破損した と思われる形跡であり，同様の現象はき裂全体を通して他 にもいくつ加観察された. 粒子架橋領域の損傷は, 応力遮 蔽効果による応力桩大係数（ $\left.K_{\mathrm{IS}}\right)$ を低下させるため, き 裂先端での応力払大係数 $\left(K_{\text {Itip }}\right)$ が増加し, 測定される破 壊勒性值（ $K_{\mathrm{IC}} ）$ が小さくなる。これは, 図 9 に示すよう に繰り返し疲労試験後の $K_{\text {IC }}$ が, SEPB 法によって得ら れた $K_{\mathrm{IC}}$ よりも低下していることからも明らかである。 また， $K_{\text {Imax }}$ が大きいほどき裂の非線形挙動（き裂進展な ど）が大きく，き裂面でのフレッチング損傷が顕著にな り，K $K_{\mathrm{IC}}$ むさくなったものと考えられる.

Dauskardt らは， $K_{\text {Imax }}$ を急激に変化させた場合の部分 安定化ジルコニア (PSZ) やアルミナ複合材料の疲労き裂 進展試験を行い, PSZ の場合には， $K_{\operatorname{Imax}}$ を急激に減少す

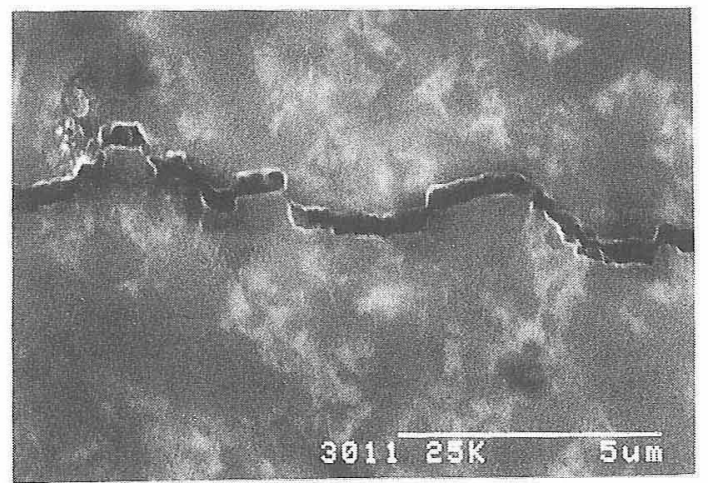

(a)

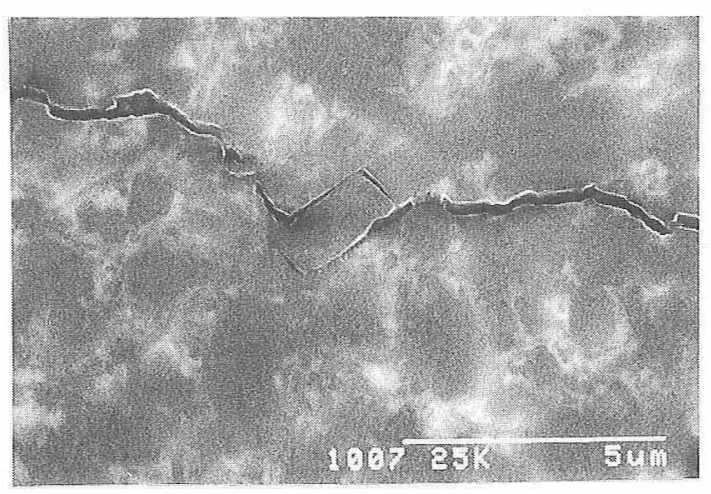

(b)

Fig. 10. Scanning electron micrographs of fatigue crack. (a) crack surface asperities, (b) crack bridging. 
ると, き裂進展速度は急激に減少した後, 徐々に増加に転 じることを報告している。これは, 応力誘起変態による高 勒化が，K $K_{\operatorname{Imax}}$ が大きいほど顕著であることに起因してい る18). 一方, SiC一アルミナ複合材料の場合には, $K_{\operatorname{Imax}}$ を 急激に減少すると, $\mathrm{d} a / \mathrm{d} N$ も急激に低下したのち，更に 徐々に低下することを報告しており，これは本実験と類似 した結果となっている19)。

図11は本実験に㧍ける疲労き裂進展挙動をモデル的に示 したものである.図11(a)に示すような $K_{\text {Imax }}$ 漸減試験で は，粒子架橋領域が高い $K_{\text {Imax }}$ で大きな損傷をうけている ため, $K_{\operatorname{Imax}}$ 值を下げた後でも, き裂進展速度は急激には 小さくならない。新しい $K_{\operatorname{Imax}}$ のもとでき裂進展がおこ り，粒子架橋による応力遮蔽効果 $\left(K_{\mathrm{IS}}\right)$ が大きくなるの に従ってき裂進展速度は緩やかに低下し, 最終的には一定 值になるものと考えられる。一方， $K_{\operatorname{Imax}}$ 漸増試験では， 疲労予き裂を $K_{\operatorname{Imax}}=4.5 \mathrm{MPa} \sqrt{\mathrm{m}}$ という条件で導入した ため，粒子架橋領域が大きく破壊されている，そのため， $K_{\text {Imax }}$ が小さな場合でも破壊靶性值が十分に大きくなら ず，図11(b)に示すように， $K_{\operatorname{Imax}}$ を上げた後, き裂進展 速度は急激に変化し, 粒子架橋領域の損傷に伴って緩やか にき裂進展速度は大きくなるような挙動を示すことが予想 される.以上の考察は，図 3 及び図 4 の実験結果と打 むね一致しており, 繰り返し応力下での粒子架橋領域の損 傷が窒化ケイ素の疲労き裂進展挙動に大きな影響を及ぼし ていいることを示している7) 15).

本実験で観察された不連続な疲労き裂進展挙動は, 窒化 ケイ素3)， $\mathrm{SiC}$ ウイスカ強化アルミナ複合材料11)などで も報告されている，不連続な疲労き裂進展挙動が観察され る理由としては, 粒子架橋領域の破壊 $\rightarrow$ 破壊勒性の低下 $\rightarrow$ き裂進展の加速 $\rightarrow$ 粒子架橋の再構築という過程が，微視的 に繰り返されていることが考えられる。また，本実験での き裂前縁は $10 \mathrm{~mm}$ という厚さを持っているため, 弱い部 分からき裂が進展すると考えると, 試験片表面のき裂進展
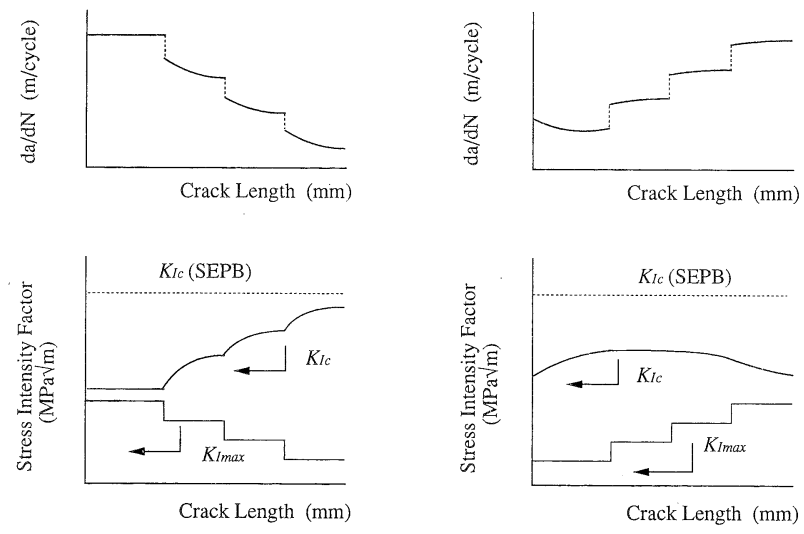

(a) KImax-Decreasing Test

(b) KImax-increasing Test

Fig. 11. Schematic representation of the relationship between fatigue crack growth rate and fracture toughness under cyclic loading. (a) $K_{\text {Imax }}$-decreasing condition, (b) $K_{\text {Imax }}$-increasing condition.
速度は微視的に見れば不均一となる．更に，き裂先端近傍 で，窒化ケイ素と粒界ガラス相との弾性不均一に起因した マイクロクラックが生成し，これが主き裂と合体すること によって不連続なき裂進展が起こる可能性もある. 今回使 用した窒化ケイ素では，焼結助剂として $\mathrm{Al}_{2} \mathrm{O}_{3}$ と $\mathrm{Y}_{2} \mathrm{O}_{3}$ を 計 $15 \mathrm{wt} \%$ 含んで扔り，粒界には多くのガラス相が存在す る.この構造は, ウイスカー強化複合材料に類似して抢 り，き裂先端近傍で不均一応力場によるマイクロクラック が生成する可能性はある11)。同様の考察は，高津らに よってもなされて抢り22)，窒化ケイ素の疲労き裂進展挙 動に及ぼす粒界ガラス相の影響も重要であると考えられ る。しかしながら，不均一なき裂進展挙動の詳細な原因に ついては本実験結果だけでは不明である。

粒子架橋領域の損傷は，き裂面の接触によるフレッチン グによると考えられるため，き裂開口 $K_{\mathrm{open}}$ を調べること は重要である。図 7 から分かるように， $K_{I \max }=3.90$ $\mathrm{MPa} \sqrt{\mathrm{m}}$ の場合, $\Delta K<2.7 \mathrm{MPa} \sqrt{\mathrm{m}}(R>0.30)$ の範囲 では， $\Delta K$ に伴うき裂進展速度の低下は急激に小さくなっ ている.図 8 に示すように，き裂開口応力拡大係数が $K_{\text {open }}=1.0 \sim 1.2 \mathrm{MPa} \sqrt{\mathrm{m}}$ であることを考えると，これは $K_{\text {Imin }}>K_{\text {open }}$ の領域に対応している. 寸なわち, 繰り返し 応力による粒子架橋領域の破壊は, き裂面の接触のない $K_{\text {Imin }}>K_{\text {open }}$ の範囲では少なく，き裂面の不整合によるき 裂のフレッチング損傷の影響が大きいことを示している.

以上の実験結果は, 長いき裂の繰り返しき裂進展は, 静 荷重き裂進展が粒子架橋領域のフレッチング損傷によって 加速されるというメカニズムを裏づける結果となってい る.

\section{5. 結 言}

セラミックスの疲労き裂進展速度を測定するたるめの方 法として， $P_{\mathrm{t}}$ スパッタ膜を用いたクラックゲージ法を適 用し, 常圧燒結窒化ケイ素の繰り返し疲労き裂進展試験を 実施した，窒化ケイ素のき裂進展速度は必ずしも一様では なく, き裂進展速度が急に変化する不均一な速度のき裂進 展挙動が認められた。き裂進展は， $K_{\operatorname{Imax}}$ 漸減試験と $K_{\text {Imax }}$ 漸増試験では異なる挙動を示した. 応力比の影響 は， $K_{\text {Imin }}>K_{\text {open }}$ の範囲では顕著には認められなかった。 また疲労試験後の破壊勒性 $K_{\mathrm{IC}}$ は SEPB 法で測定した值 よりも小さく, この傾向は $K_{\text {Imax }}$ が大きい場合ほど顕著で あった。 以上の実験結果から, 窒化ケイ素の繰り返し荷重 下によるき裂進展は, 静荷重き裂進展が, 粒子架橋領域の フレッチング損傷によって加速されるというメカニズムを 裏づける結果が得られた。

謝辞 本研究を遂行するに当たり，ご助力を頂きました東 京工業大学工業材料研究所・赤津 隆助手に感謝致します。 た, 試験片の試作にご協力頂きました, 日産自動車(株)総合研究 所 · 浦本清弘氏, 堀 年雄氏, 宮村利春氏に感謝致します。

\section{文献}

1) S. M. Wiederhorn, "Fracture Mechanics of Ceramics", Vol. 2, Ed. by R. C. Bradt et al., Plenum, New York (1974) pp. 
$613-46$.

2) A. G. Evans, Int. J. Fract., 16, 485-98 (1980).

3) 岸本秀弘, 上野明, 河本 洋, 材料, 36, 1122-27 (1987).

4) A. Ueno, H. Kishimoto, H. Kawamoto and M. Asakura, Eng. Fract. Mech., 40, 913-20 (1991).

5) 岸本秀弘, 上野 明, 河本 洋, 藤井康義, 材料, 38, 1212-17 (1989).

6) 上野 明, 岸本秀弘, 河本 洋, 材料, 41, 253-59 (1992).

7) 上野 明, 岸本秀弘, 河本 洋, 山中洋一, 材料, 41, 495-501 (1992).

8）岸本秀弘, 上野明, 河本洋, 日本機械学会論文集, 58-A, 2011-17 (1992).

9）小川武史，日本機械学会論文集，57-A, 492-99 (1991).

10）小川武史，材料，40, 1479-84 (1991)。

11）小川武史，越知篤則，戸梶恵郎，日本機械学会論文集， 58-A, 639-46 (1992).

12）高橋 学, 武藤睦治, 岡本寛巳, 老川恒夫, 材料, 40 , 588-94 (1991)

13）高橋 学, 武藤睦治, 日本機械学会論文集, 57-A, 261521 (1992)。
14) T. Tanaka, N. Okabe, H. Nakayama and Y. Ishimaru, Fatigue Fract. Engng. Mater. Struct., 15, 643-53 (1992).

15) M. Okazaki, A. J. Mcevily and T. Tanaka, Metall. Trans. 22A, 1425-34 (1991).

16) R. H. Dauskardt, W. Yu and R. O. Ritchie, J. Am. Ceram. Soc., 70, C248-52 (1987).

17) R. H. Dauskardt, D. B. Marshall and R. O. Ritchie, J. Am. Ceram. Soc., 73, 893-903 (1990).

18) R. H. Dauskardt, W. C. Carter, D. K. Veirs and R. O. Ritchie, Acta Metall., 38, 2327-36 (1990).

19) R. H. Dauskardt, M. R. James, J. R. Porter and R. O. Ritchie, J. Am. Ceram. Soc., 75, 759-71 (1992).

20）野口新二，布村成具，日本材料学会第38回全国大会論文集, 73-75 (1989).

21) F. Guiu, M. Li and M. J. Reece, J. Am. Ceram. Soc., 75, 2976-84 (1992).

22）高津 学, 大矢寛二, 安藤雅史, セラミックス論文集, 98, 490-98 (1990).

23) S. Lathabai, J. Rodel and B. R. Lawn, J. Am. Ceram. Soc., 74, 1340-48 (1991). 